\title{
Farklı Dolgu Malzemeleri ile Sabitlenen Zıvanaların Yığma Taş Bloklarının Kayma Dayanımına Etkisi
}

\author{
Şükran Tanrıverdi ${ }^{1 *}$, Tülin Çelik ${ }^{2}$ \\ 1* Aksaray Üniversitesi, Mühendislik Fakültesi, İnşaat Mühendisliği Bölümü, Aksaray, Türkiye, (ORCID: 0000-0001-9751-5788), sukran_tugrulelci@hotmail.com \\ ${ }^{2}$ Aksaray Üniversitesi, Mühendislik Fakültesi, İnşaat Mühendisliği Bölümü, Aksaray, Türkiye, (ORCID: 0000-0001-8638-9579), tulinsandikci@gmail.com
}

(İlk Geliş Tarihi 9 Nisan 2021 ve Kabul Tarihi 27 Haziran 2021)

(DOI: $10.31590 /$ ejosat.912304)

ATIF/REFERENCE: Tanrıverdi, Ş. \& Çelik, T. (2021). Farklı Dolgu Malzemeleri ile Sabitlenen Zıvanaların Yığma Taş Bloklarının Kayma Dayanımına Etkisi. Avrupa Bilim ve Teknoloji Dergisi, (25), 347-354.

\begin{abstract}
Özet
Zıvanalar, kesme taşları birbirine bağlamak için kullanılan çelikten yapılmış bağlantı elemanlarıdır. Tarihi yapılardaki zıvana uygulaması, kesme taşların üst ve alt kısımlarının yuvarlak şekilde oyulması ve bunların içine kurşun akıtılıp zıvana çeliğinin yerleştirilmesiyle yapılmıştır. Bu uygulama ile taşıyıcı duvarların davranışı sünek hale getirilerek yapının bütünlüğü korunmuştur. Geleneksel olarak kesme taşlardaki zıvana uygulamalarında dolgu malzemesi olarak kurşun kullanılmıştır. Bu çalışmada, zıvanalarda kullanılan kurşun dolgu malzemesine alternatif olarak farklı dolgu malzemeleri kullanılmış ve sonuçları karşılaştırılmıştır. Çalışma kapsamında dolgu malzemesi olarak kurşun, epoksi ve çimento şerbeti kullanılmıştır. Üç farklı malzeme ile sabitlenen zıvanaların taş bloklar üzerindeki kayma dayanımları incelenmiştir. Çalışma sonucunda çimento şerbeti ile yapılan deney numunelerinde sıyrılmalar gözlemlenmiş ve yük taşıma kapasiteleri diğer deney numunelerine kıyasla daha düşük çıkmıştır. Epoksi kullanılarak yapılan deney numunelerinde ise yükte ani düşmeler meydana gelmiş ve buna bağlı olarak taş bloklar üzerinde büyük hasarlar meydana gelmiştir. Tarihi yapıların yapımında geleneksel olarak kullanılan kurşun malzemesinin diğer malzemelere kıyasla daha sünek bir davranış sergilediği görülmüştür. Bu çalışma ile kurşunun tarihi yapılarda kullanılmasındaki önemi daha net olarak ortaya konulmuştur.
\end{abstract}

Anahtar Kelimeler: Kurşun, Epoksi, Çimento şerbeti, Zıvana, Kayma dayanımı, Tarihi yapılar.

\section{The Effect of Dowels Fixed with Different Filling Materials on the Shear Strength of Masonry Stone Blocks}

\begin{abstract}
Dowels are steel made elements connecting the cut stones to each other. Dowel applications in the historical structures are performed by carving circularly the cut stones, then injecting lead mine into these carved holes and finally placing the dowels properly. As a result of this application, the behavior of the carrier walls are turned into more ductile. Traditionally lead mine has been used as filling material in dowel applications. In this study, different filling materials were used as an alternative to the lead filling material used in dowels and the results were compared. In the scope of the study, lead, epoxy and cement grout were used as filling materials. The shear strength of the dowels fixed with three different materials on the stone blocks was investigated. As a result of the study, slipping was observed in the test samples made with cement grout and their load carrying capacities were found to be quite low compared to other test samples. On the other hand, in the experimental samples made using epoxy, sudden drops in the load occurred and major damages occurred on the stone blocks as a result. The lead material traditionally used in the construction of historical structures displayed a more ductile behavior compared to other materials. With this study, the importance of lead in the use of historical structures has been revealed more clearly.
\end{abstract}

Keywords: Lead, Epoxy, Cement grout, Tenon, Shear strength, Historical structures.

\footnotetext{
*Sorumlu Yazar: sukran_tugrulelci@hotmail.com
} 


\section{Giriş}

Tarihi yapılar, geçmişten günümüze kadar gelen ve toplumun ortak değerlerini yansıttıkları için gelecek nesillere aktarılması gereken mirasımızdır. Tarihi yapılar geçmiş ile günümüz arasında köprü kurarak, toplumun yaşanmış kültürünü ve değerlerini gelecek nesillere anlatmaktadır. Toplumlar, üzerinde barındırdıkları bu yapıların varlıkları ile zenginleşmektedir. Tarihi yapılar bizden önce yaşayan insanlar tarafından bizlere bırakılan kültürel bir miras olup bunların korunması ve yaşatılması bizlerin en önemli görevlerinden biridir. $\mathrm{Bu}$ yapılarda yeterli mühendislik bilgisi olmadan, standartlara uygun olmayan onarım ve güçlendirme uygulamalarının yapılmaması gerekmektedir. $\mathrm{Bu}$ yapıların onarım ve güçlendirilmesinde dikkat edilmesi gereken en önemli unsur, yapının özgünlüğünü bozmadan aslına uygun malzeme kullanılarak ve yeterli mühendislik bilgisi ile yapıda onarım ve güçlendirme uygulamalarının yapılmasıdır.

Tarihi yapılarda hasarlar genellikle yapısal, zeminden kaynaklanan, hatalı malzeme kullanımı ve kötü işçilik sonucu meydana gelmektedir. $\mathrm{Bu}$ tür yapılar üzerine gelen düşey kuvvetleri taşımakta olup deprem gibi yatay kuvvetleri taşıyamadığı için hasar almakta ya da yıkılmaktadır. Tarihi yapılar tuğla ve harcın birleşimiyle meydana gelen gevrek yapılardır. Böylece deprem kuvvetlerine karşı enerji tüketme kapasiteleri de oldukça düşüktür. Bu tür yapıların sünekliliğini artırmak için metal bağlantı elemanları olan zıvana ve kenetler kullanılmaktadir.

Metal bağlantı elemanı olarak kullanılan zıvanaların yığma yapı sistemi üzerine olumlu etkileri (Ural vd., 2015) ile ilgili günümüze kadar yapılmış bazı bilimsel yayınlar ve araştırmalar olduğu görülmüştür. Bu çalışmada ele alınan zıvanaların farklı dolgu malzemeleri kullanılarak sabitlenmesinin yı̆̆ma taş bloklar üzerine etkisi ile ilgili yapılmış bilimsel çalışmaya rastlanılmamıştır. Bu çalışma günümüzde yapılan tarihi yapıların onarım ve güçlendirilmesi çalışmalarında, zıvanaların sabitlenmesinde hangi malzemelerin kullanılması gerektiği konusunda iyi bir referans olacağı düşünülmektedir. Çelik ve Tanrıverdi (2021), çalışmasında farklı çaptaki zıvanaların kurşun ile sabitlenmesinin taş bloklar üzerindeki etkilerini araştırmak amaciyla 15 adet numune üzerinde kayma dayanım testleri gerçekleştirilmiştir. Deney sonuçları birbirleri ile karşılaştırılmıştır. Sonuçlar doğrultusunda onarım ve güçlendirmede kullanılan zıvana demirlerinin kurşun ile sabitlenmesinin önemi ve zıvana demirlerinin çaplarının nasıl olması gerektiği konusunda önerilerde bulunulmuştur. Nikolic vd. (2019), yaptıkları çalışmada, kuru taş yığma yapıları metal bağlantı elemanı olan dübel ve kenetleri ile güçlendirilmiştir. Kuru taş yığma yapıların davranışlarının sayısal modeli sonlu ayrık eleman yöntemi ile modellenerek incelenmiştir. Metal bağlantı elemanlarının malzeme ve geometrik modeli geliştirilmiş ve sonlu ayrık eleman modeli ile analiz edilmiştir. Elde edilen sonuçlara göre, dinamik davranışta kuru taş yığma yapılarda kullanılan metal bağlantı elemanları, tarihi anıtların davranışlarının simülasyonunda uygulanan modelin performansını olumlu yönde etkilediğini göstermiştir. Tarihi binaların depreme dayanıklılığını arttırmada metal bağlantı elemanları faydalı olmuştur. Soti ve Barbosa (2019), çalışmalarında yığma duvarın yüzeyine yakın olarak monte edilen çelik dübeller ile güçlendirilmiş numuneler deneysel ve sayısal olarak modellemişlerdir. Donatısız yığma duvar ve güçlendirilmiş yığma duvarlara ait modellerin deneysel ve sayısal sonuçları birbirileri ile kıyaslanmıştır. Deney sonuçlarına göre çelik dübellerin, duvarların deformasyon kapasitesini iyileştirmede etkili olduğu görülmüştür. Simonovic ve Simonovic (2018), yaptıkları çalışmada yığma duvarları, çelik 1zgara ve FRC dübelli betonarme paneller ile onarım ve güçlendirilmesi yapılmıştır. $\mathrm{Bu}$ iki farklı güçlendirme uygulamasının analizleri yapmış ve sonuçları birbirleri ile kıyaslayarak avantajlarını ve dezavantarını ifade etmişlerdir. Araştırma sonuçlarına göre güçlendirme için uygulanan sistemlerinin kalitesi üzerindeki en önemli etki duvarın yeterli bir şekilde güçlendirilmesi gereken elemanların rijitlik seçimi ile gerçekleşmiştir. Ural vd. (2015) çalışmalarında farklı kenet ve zıvana sistemlerine sahip yığma duvar numuneleri üzerinde deneyler gerçekleştirmiş ve bu deney sonuçlarına göre sistemlerin yı̆̆ma duvarların kesme kapasitesine etkisini inceleyerek bir takım önerilerde bulunmuşlardır. Demir (2012), çalışmasında çok tabakalı tarihi duvarların kayma davranışına etkisini incelemiştir. Değişken olarak, eksenel gerilme düzeyi, kenet ve zıvana kullanımı ve dış tabakalar arasında iç moloz dolguyu kullanmıştır. Deneysel çalışma sonucunda kenetlerin kullanılması çatlak dağılımını etkilemekte ve kullanılan küfeki taşının çekme dayanımının nispeten düşük olması nedeniyle kenetlerin etkinliklerinin bir seviyede sinırlandığı sonucuna varılmıştır. Özyurt vd. (2018), yaptıkları çalışmada düşey delikli yığma tuğlalar ile üretilmiş duvarların çelik levhalar ile güçlendirimesini deneysel olarak incelemiştir. Çalışma kapsamında biri referans dört taneside çelik levhalar ile güçlendirilmiş toplamda beş adet deney elemanı üzerinde test yapılmıştır. Sonuç olarak çelik levhalar ile güçlendirilmiş deney elemanlarının yük taşıma kapasiteleri, süneklikleri, rijitlikleri ve dayanımlarının arttığı tespit edilmiştir.

$\mathrm{Bu}$ çalışma kapsamında farklı dolgu malzemesi olarak kurşun, epoksi ve çimento şerbeti kullanılmıştır. Yapılan deneysel çalışmada zıvanaların dolgu malzemeleri ile sabitlenmesinin taş bloklar üzerindeki kayma dayanımlarına etkisi deneysel olarak incelenmiştir.

\section{Malzeme ve Yöntem}

\subsection{Yığma Birimler ve Zıvanaların Özellikleri}

Çalışmada yığma birim olarak kullanılan volkanik kökenli tüf taşı, Aksaray İli'nde bulunan Sevinçli Kasabası'ndan çıkartılmaktadır. Deneyde kullanılan taş bloğun boyutları 200x300x600 $\mathrm{mm}^{3}$ 'dür. Tablo1'de çalışmada kullanılan yığma taş blokların fiziksel sonuçları verilmektedir. 
Tablo 1. Deneyde kullanılan yığma taş blokların fiziksel deney sonuçları (Uslu, 2018)

\begin{tabular}{lc}
\hline Test Türü / Birimi & Sonuç \\
\hline Mohs Sertlik & 3 \\
Dijital Schmidt Çekici Sertliği & $35(33-37)$ \\
Kuru Birim Hacim Ağırlığı $\left(\mathrm{g} / \mathrm{cm}^{3}\right)$ & 1,97 \\
Doygun Birim Hacim Ağırlığı $\left(\mathrm{g} / \mathrm{cm}^{3}\right)$ & 1,52 \\
Porozite (\%) & 22,78 \\
Ağırlıķa Su Emme (\%) & 15,00 \\
Nemlilik (\%) & 1,15 \\
Renk & $\mathrm{Gri}$ \\
Doluluk Oranı (\%) & 76 \\
Ultrasonik Hız ( $\mu \mathrm{s})$ & 60,0 \\
Ultrasonik Hız (km/s) & 5,40 \\
pH (100 mL suda) & 8,87 \\
Suda Çözünen Toplam Tuz ( $\mu \mathrm{S}-25 \mathrm{~mL}$ & 590 \\
suda) & 0,58 \\
Suda Çözünen Toplam Tuz $(\%-25 \mathrm{~mL}$ suda) & 23 \\
Darbe Direnci (kgcm/cm $\left.{ }^{3}\right)$ & \\
\hline
\end{tabular}

Tarihi yapılarda yığma birim olarak taş, tuğla, kerpiç, ahşap gibi malzemeler kullanılmaktadır. $\mathrm{Bu}$ malzemelerin basınç dayanımları yüksek, çekme dayanımları ise oldukça düşüktür. Deneyde kullanılan volkanik kökenli tüf taşı üzerinde Kâgir birimlerin basınç dayanımının tayini TS EN 772-1+A1 (2015) standartı dikkate alınarak basınç dayanım testleri ve Beton kâgir birimlerin eğilmede çekme dayanım tayini TS EN 772-6 (2004) standartına göre çekme dayanım testleri yapılmıştır. Basınç dayanım testleri standartta belirtildiği şekilde $50 \times 50 \times 50 \mathrm{~mm}^{3}$ boyutlarında tüf taşı kesilerek, 6 adet taş üzerinde test edilmiştir. Deneyde kullanılan yığma taş blokların basınç dayanım sonuçları Tablo 2'de gösterilmiştir. Taşın basınç dayanımları kırılma yükünün uygulanan alana bölünmesiyle elde edilmiştir. Yapılan basınç dayanım testi sonucunda tüf taşının ortalama basınç dayanımı 4,13 MPa ve standart sapması 0,66 MPa elde edilmiştir. Tüf taşının eğilmede çekme dayanımını elde etmek

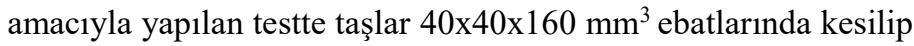
oda sıcaklığında kurutulduktan sonra 6 adet taş teste tabi tutulmuştur. Yapılan test sonucunda taşın ortalama eğilme çekme dayanımı Tablo 3'de belirtildiği gibi $0,71 \mathrm{MPa}$ olarak hesaplanmıştır. Yığma taş blokların eğilmede çekme dayanımları Denklem 1 ile hesaplanmıştır. Yapılan testlerle tarihi yapılarda kullanılan yığma taşların, basınç dayanımlarının çekme dayanımlarına göre daha fazla olduğu kanıtlanmıştır.

$\mathrm{R}_{\mathrm{tf}}=\frac{P L}{b d^{2}}$
Tablo 2. Deneyde kullanılan yığma taş birimlerin basınç dayanımı sonuçları

\begin{tabular}{ccccc}
\hline Numune No & \multicolumn{2}{c}{$\begin{array}{c}\text { Enkesit } \\
\text { boyutları } \\
(\mathrm{mm})\end{array}$} & $\begin{array}{c}\text { Kirılma } \\
\text { Yükü (N) }\end{array}$ & $\begin{array}{c}\text { Basıç } \\
\text { Dayanımı } \\
(\mathrm{MPa})\end{array}$ \\
\cline { 2 - 3 } & $\mathrm{a}$ & $\mathrm{b}$ & & 5,06 \\
$\mathrm{~A} 1$ & 50 & 50 & 12650 & 4,34 \\
A2 & 50 & 50 & 10850 & 3,43 \\
A3 & 50 & 50 & 8570 & 3,98 \\
A4 & 50 & 50 & 9970 & 4,58 \\
A5 & 50 & 50 & 11450 & 3,38 \\
A6 & 50 & 50 & 8450 & 4,13 \\
\hline \multicolumn{5}{c}{ Otandart Sapma } \\
\hline
\end{tabular}

Tablo 3. Deneyde kullanılan yı̆̆ma taş birimlerin ĕgilmede çekme dayanım sonuçları

\begin{tabular}{ccc}
\hline Numune No & $\begin{array}{c}\text { Kirılma Yükü } \\
(\mathrm{N})\end{array}$ & $\begin{array}{c}\text { Eğilmede } \\
\text { Çekme } \\
\text { Dayanımı } \\
(\mathrm{MPa})\end{array}$ \\
\hline A1 & 490 & 0,77 \\
A2 & 490 & 0,62 \\
A3 & 560 & 0,88 \\
A4 & 500 & 0,68 \\
A5 & 450 & 0,59 \\
A6 & 570 & 0,72 \\
\hline
\end{tabular}

Tarihi yapıların onarım ve güçlendirilmesinde bağlantı elemanları olarak kenetler ve zıvanalar kullanılmaktadır. Bu malzemeler ile yapının dayanımı, taşıma kapasiteleri ve sünekliliği artmaktadır. Çalışmada kullanılan zıvanaları temsilen $10 \mathrm{~mm}$ çapına sahip tij demirleri kullanılmıştır. Zıvanaların çekme dayanımlarını belirlemek amacıyla, TS EN ISO 6892-1 (2020) standartında belirtildiği şekilde çekme testleri yapılmıştır. Deney sonucunda zıvanaların çekme dayanımları yaklaşık olarak 290 MPa olarak hesaplanmıştır. Çekme dayanımı Denklem 2 ile hesaplanmıştır.

$\mathrm{R}_{\mathrm{m}}=\mathrm{F}_{\mathrm{m}}$

$\mathrm{R}_{\mathrm{m}}$ : Zıvanaların çekme dayanımı, $\mathrm{F}_{\mathrm{m}}$ ise deney sırasında akmanın gerçekleşmesi sonucunda zıvananın dayandığı en büyük yüktür.

\subsection{Deneyde Kullanılan Epoksinin Özellikleri}

Yapılan deneysel çalışmada zıvanaların taş bloklar üzerine sabitlenmesinde MasterBrace ADH 1406 adlı epoksi tamir harc1 kullanılmıştır. MasterBrace ADH 1406, epoksi esaslı, iki bileşenli, tamir, ankraj ve montaj harcıdır. Kullanılan epoksinin teknik özellikleri Tablo 4'de verilmiştir. 
Tablo 4. MasterBrace ADH 1406'nın teknik özellikleri (URL-1)

\begin{tabular}{|c|c|}
\hline \multicolumn{2}{|l|}{ Malzeme Yapısı } \\
\hline MasterBrace $®$ ADH 1406 Bileşen A & Epoksi Reçine \\
\hline MasterBrace $®$ ADH 1406 Bileşen B & Epoksi Sertleştirici \\
\hline Renk & Gri \\
\hline Karışım Yoğunluğu & $1,70+0,05 \mathrm{~kg} /$ litre \\
\hline \multicolumn{2}{|l|}{ Basınç Dayanımı (TS EN 196) } \\
\hline 1 gün & $30 \mathrm{~N} / \mathrm{mm}^{2}$ \\
\hline 7 gün & $60 \mathrm{~N} / \mathrm{mm}^{2}$ \\
\hline \multicolumn{2}{|l|}{ Eğilme Dayanımı (TS EN 196) } \\
\hline 1 gün & $17 \mathrm{~N} / \mathrm{mm}^{2}$ \\
\hline 7gün & $25 \mathrm{~N} / \mathrm{mm}^{2}$ \\
\hline \multicolumn{2}{|l|}{ Yapışma Dayanımı (28 gün) } \\
\hline Betona & $>3,0 \mathrm{~N} / \mathrm{mm}^{2}$ \\
\hline Çeliğe & $>3,5 \mathrm{~N} / \mathrm{mm}^{2}$ \\
\hline Uygulanacak Zeminin Sicaklığ1 & $+5^{\circ} \mathrm{C}+30^{\circ} \mathrm{C}$ \\
\hline Kullanma Süresi $\left(+20^{\circ} \mathrm{C}\right)$ & 40 dak. \\
\hline $\begin{array}{l}\text { Yeniden Kaplanabilme Süresi } \\
\left(+20^{\circ} \mathrm{C}\right)\end{array}$ & 18-24 saat \\
\hline \multicolumn{2}{|l|}{ Üzerinde Yürünebilme Süresi } \\
\hline \multicolumn{2}{|l|}{$\left(+20^{\circ} \mathrm{C}\right)$} \\
\hline Servis Sicaklığ & $-15^{\circ} \mathrm{C}+90^{\circ} \mathrm{C}$ \\
\hline Tam Kürlenme Süresi $\left(+20^{\circ} \mathrm{C}\right)$ & 7 gün \\
\hline
\end{tabular}

\subsection{Deneyde Kullanılan Kurşunun Özellikleri}

Tablo 5'de deneyde kullanılan kurşun dolgu malzemesinin fiziksel ve mekanik özellikleri gösterilmiştir.

Tablo 5. Deneyde kullanılan kurşunun fiziksel ve mekanik özellikleri (URL-2)

\begin{tabular}{|c|c|}
\hline Fiziksel Özellikleri & \\
\hline Kompozisyon \% & Pb:99.9 \\
\hline Özgül Ağırlığg $\left(\mathrm{Kg} / \mathrm{Dm}^{3}\right)$ & 11,35 \\
\hline Ergime Sicaklığ $1\left({ }^{\circ} \mathrm{C}\right)$ & 326 \\
\hline Isı İletkenliği $25^{\circ} \mathrm{C}$ Tavlanmış $\left(\mathrm{Kcal} / \mathrm{Sa} / \mathrm{Cm} /{ }^{\circ} \mathrm{C}\right)$ & 29,2 \\
\hline Genleşme Katsayısı $\left(20-200{ }^{\circ} \mathrm{C}\right)\left({ }^{\circ} \mathrm{C}\right)$ X 10-6 & 29,3 \\
\hline Isınma Isıs1 $\left(20^{\circ} \mathrm{C}\right),\left(\mathrm{Kcal} / \mathrm{Kg} /{ }^{\circ} \mathrm{C}\right)$ & 0.031 \\
\hline \multicolumn{2}{|l|}{ Mekanik Özellikleri } \\
\hline Gerilmede Elastik Modül $\left(\mathrm{Kg} / \mathrm{Cm}^{2}\right) \mathrm{X} 10^{3}$ & 140 \\
\hline Çekme Dayanıklılı̆g $24^{\circ} \mathrm{C}\left(\mathrm{Kg} / \mathrm{Cm}^{2}\right)$ & 170 \\
\hline Akma Dayanıklılı̆g $24^{\circ} \mathrm{C}\left(\mathrm{Kg} / \mathrm{Cm}^{2}\right)$ & 115 \\
\hline Uzama (5.Cm.De)\% & 57 \\
\hline Dayanıklılık Sinırı $(10 ? \mathrm{~Hz})\left(\mathrm{Kg} / \mathrm{Cm}^{2}\right)$ & 50 \\
\hline Kayma Dayanıklılığ 1 (Yılda \%0,1) $\left(\mathrm{Kg} / \mathrm{Cm}^{2}\right)$ & 21 \\
\hline
\end{tabular}

\section{Deney Numunelerinin Hazırlanması}

$\mathrm{Bu}$ çalışmada tarihi yapıların onarım ve güçlendirilmesinde kullanılan zıvanaların farklı dolgu malzemeleri ile yığma taş bloklara sabitlenerek kayma dayanımları deneysel olarak incelenmiştir. Deney çalışmasında değişken olarak ele alınan dolgu malzemesi olarak kurşun, epoksi ve çimento şerbeti kullanılmıştır. Her bir numuneden 5'er adet toplamda 15 adet numune deneye tabi tutulmuştur. Deneysel çalışmaya başlamadan önce Şekil 1 (a)'da gösterildiği gibi 200x300x600 $\mathrm{mm}^{3}$ bıyutlarındaki yığma taş üzerine kullanılan zıvana çapından $(10 \mathrm{~mm})$ büyük olacak şekilde $12 \mathrm{~mm}$ çapında zıvana yuvaları açılmıştır. Şekil 1 (b)'de deneyde kullanılan zıvanayı temsil eden $10 \mathrm{~mm}$ çapındaki sonsuz dişli gösterilmiştir.

Genellikle tarihi yapılarda kullanılan zıvanaların uçları şişkin ortası incedir. Bunu temsilen sonsuz dişlilerin uçlarına somun geçirilmiştir. Şekil 1(c)'de yığma taş bloklar üzerine açılan zıvana yuvaları gösterilmiştir.

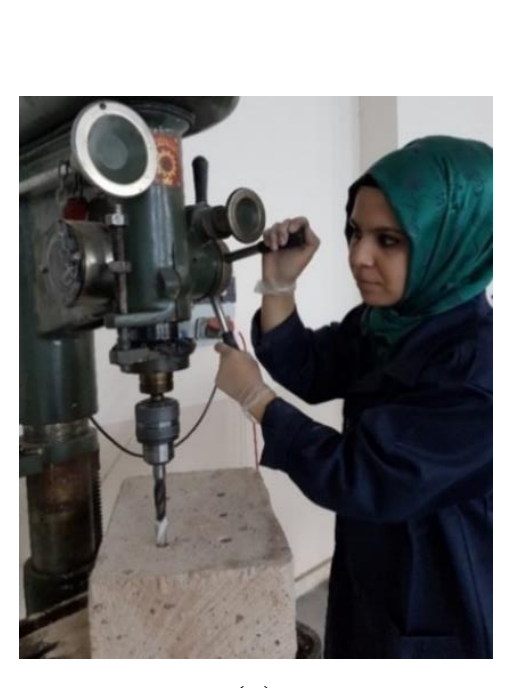

(a)

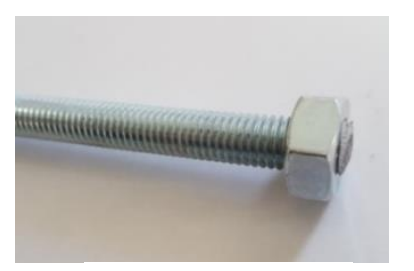

(b)

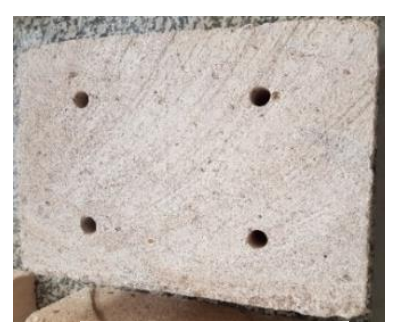

(c)
Şekil 1. a) Yığma taş blok üzerine zıvana yuvalarının açılması, b) Deneyde kullanılan zıvana, c) Deneyde kullanılan yığma taş blok

Hazırlanan numuneler, Şekil 2'de verilen deney düzeneğine yerleştirilerek deneysel çalışmalar yapılmıştır. Deneysel çalışılacak taş bloklar üzerine, 50 ton kapasiteye sahip yük hücresi ve hidrolik pompa yerleştirilmiştir. Deneyde yükleme işlemi 50 ton kapasiteye sahip hidrolik pompa ile yapılmıştır. Yük hücresi, uygulanan yüke göre çekmeye (kayma) maruz kalmakta ve çıkış ucundan belirli çekme kuvveti vererek çalışmaktadır. Bu çekme (kayma) kuvvetleri yük hücresinden alınıp, kurulan mekanizma ile bilgisayar ortamına aktarılmaktadır. Deney düzeneğindeki yükleme sistemi kuvvet kontrollü yapılıp, yükleme oranı ortalama olarak $0,3 \mathrm{kN} / \mathrm{sn}$ olarak uygulanmıştır. 


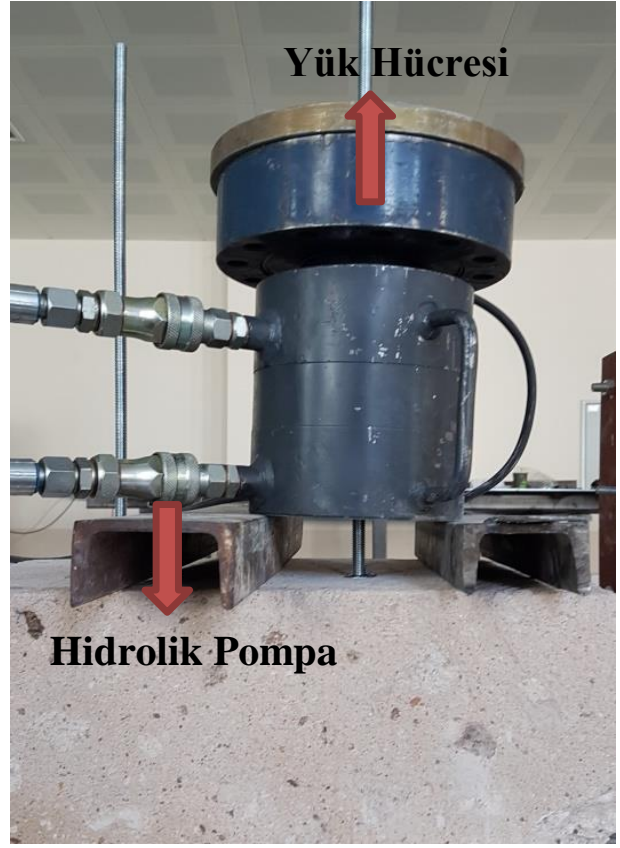

Şekil 2. Deney düzeneği

\subsection{Kurşun İle Yapılan Deney Numunelerinin Hazırlanması}

Tarihi yapılarda genellikle düşey bağlantı elemanı olarak kullanılan zıvanaların hava şartlarından etkilenip korozyona uğramasını, bu sebeple taşa zarar vermesini engellemek amacıyla zıvana oyukları kurşun ile doldurulmuştur. $\mathrm{Bu}$ çalışmada da $12 \mathrm{~mm}$ çapında açılan zıvana yuvalarına $10 \mathrm{~mm}$ 'lik zıvana görevini yapacak sonsuz dişliler Şekil 3.'de gösterildiği gibi yerleştirilmiştir. Bu zıvanalar eritilen kurşun ile sabitlenerek deneye hazır hale getirilmiş̧ir (Şekil 3). Deney sonrası taş bloklar üzerinde oluşan hasarlar Şekil 4'de verilmiștir. Geleneksel olarak kullanılan kurşun malzemesinin davranışı bu çalışma ile daha net bir şekilde ortaya konulmuştur.

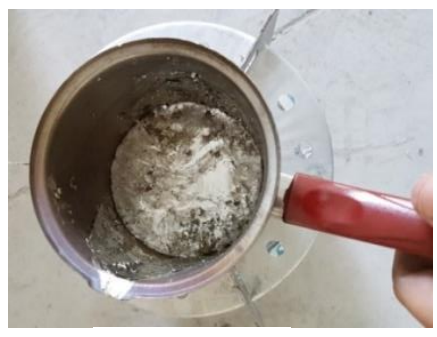

(a)

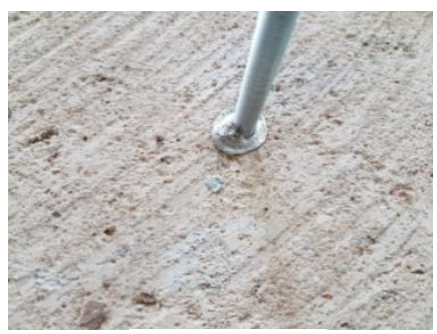

(c) (a)
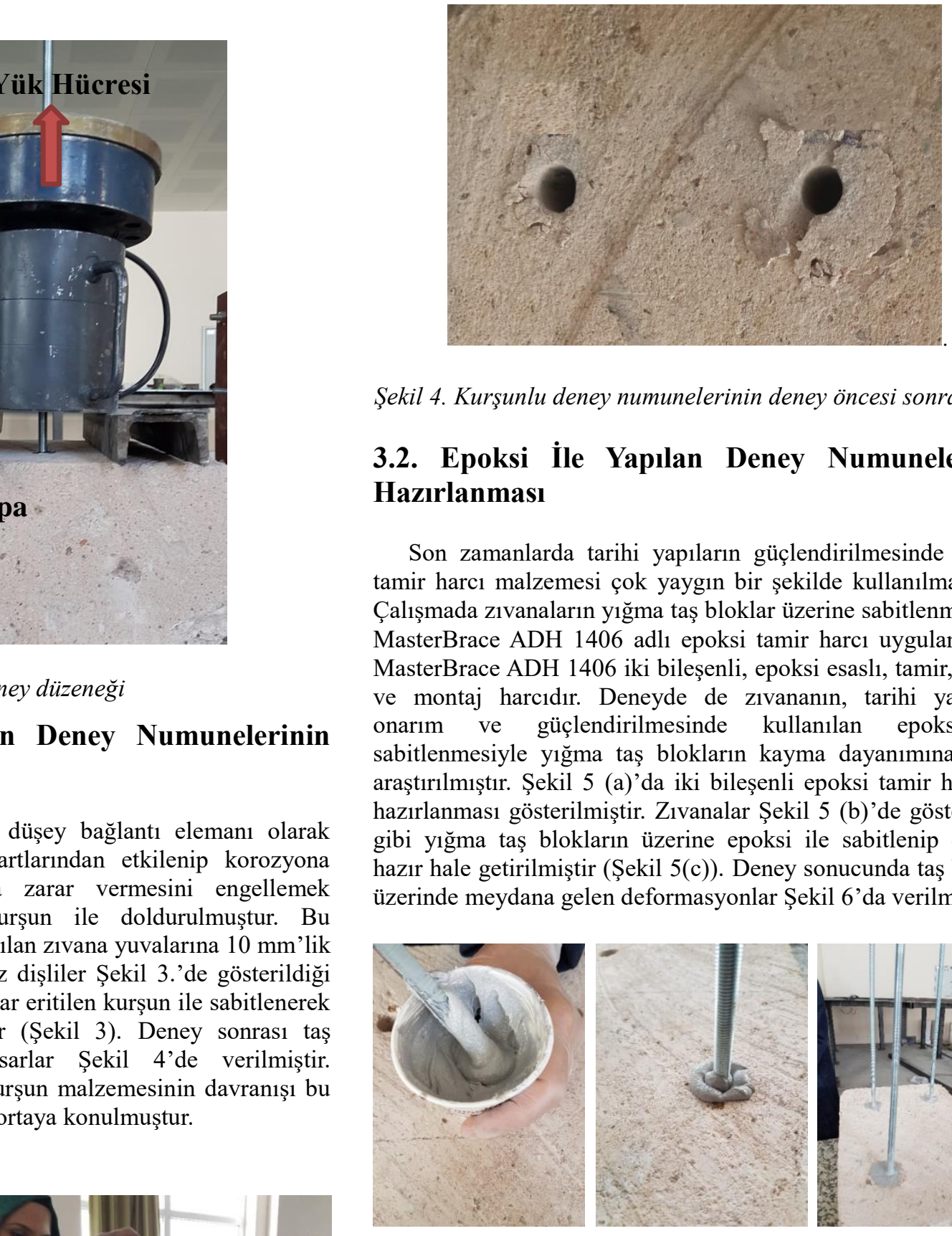

Şekil 4. Kurşunlu deney numunelerinin deney öncesi sonrası hali

\subsection{Epoksi İle Yapılan Deney Numunelerinin Hazırlanması}

Son zamanlarda tarihi yapıların güçlendirilmesinde epoksi tamir harcı malzemesi çok yaygın bir şekilde kullanılmaktadır. Çalışmada zıvanaların yığma taş bloklar üzerine sabitlenmesinde MasterBrace ADH 1406 adlı epoksi tamir harcı uygulanmıştır. MasterBrace ADH 1406 iki bileşenli, epoksi esaslı, tamir, ankraj ve montaj harcıdır. Deneyde de zıvananın, tarihi yapıların onarım ve güçlendirilmesinde kullanılan epoksi ile sabitlenmesiyle yığma taş blokların kayma dayanımına etkisi araştırılmıştır. Şekil 5 (a)'da iki bileşenli epoksi tamir harcının hazırlanması gösterilmiştir. Zıvanalar Şekil 5 (b)'de gösterildiği gibi yığma taş blokların üzerine epoksi ile sabitlenip deneye hazır hale getirilmiştir (Şekil 5(c)). Deney sonucunda taş bloklar üzerinde meydana gelen deformasyonlar Şekil 6'da verilmiştir.

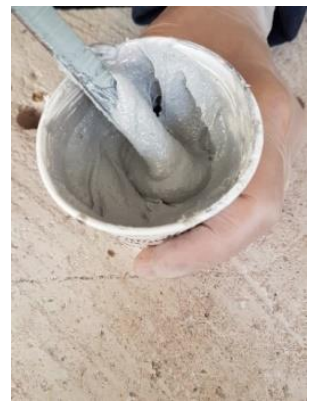

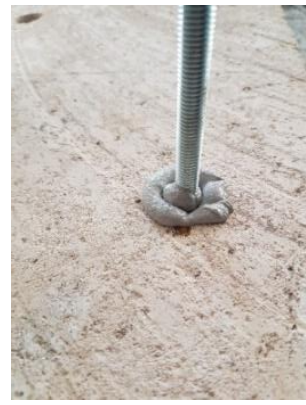

(b)

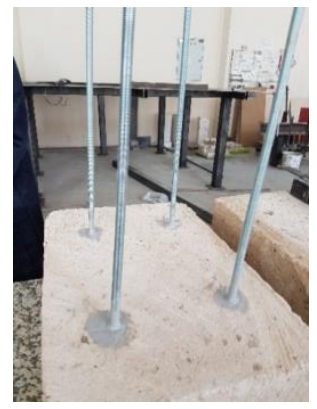

(c)
Şekil 5. a) Deneyde kullanılan epoksinin hazırlanması, b) Epoksi ile zıvananın sabitlenmesi, c) Epoksili deney numunelerinin deney öncesi hali

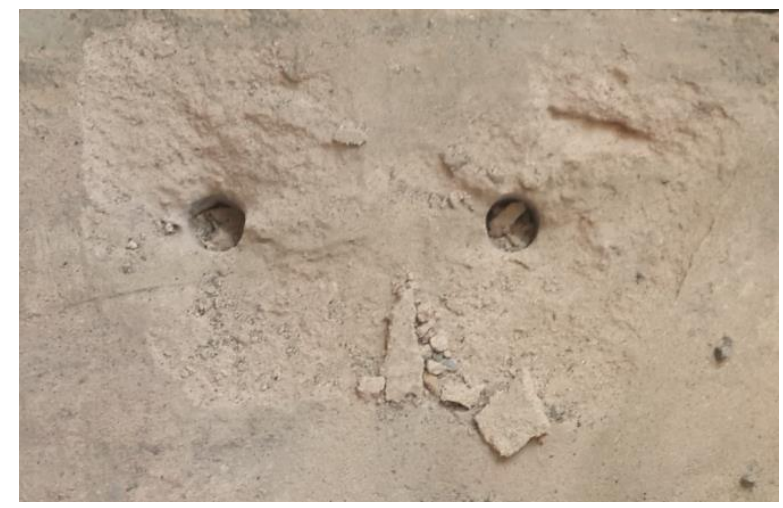

Şekil 6. Epoksili deney numunelerinin deney sonrası hali Şekil 3. a) Deneyde kullanılan kurşunun eritilmesi, b) Kurşun ile
zıvananın sabitlenmesi, c) Kurşunlu deney numunelerinin deney öncesi hali 


\section{3. Çimento Şerbeti İle Yapılan Deney Numunelerinin Hazırlanması}

Deneysel çalışmada zıvanaların taş blok üzerine sabitlenmesinde değişken olarak ele alınan malzemelerden bir diğeri de çimento şerbetidir. Tarihi yapılarda genellikle kılcal seviyede oluşan çatlaklar, enjeksiyon yardımı ile çimento şerbeti oluşturularak onarılmaktadır. Deneysel çalışmada da çimento ve su karışımından oluşan çimento şerbeti yapılmıştır. Açılan zıvana yuvalarına yerleştirilen zıvanalar taş blok üzerine çimento şerbeti ile sabitlenerek deneye hazır hale getirilmiştir (Şekil 7). Çimento şerbeti ile yapılan deney numunelerinin deney sonrası hali (taş bloklar üzerinde meydana gelen hasarlar) Şekil 8'de gösterilmiştir.

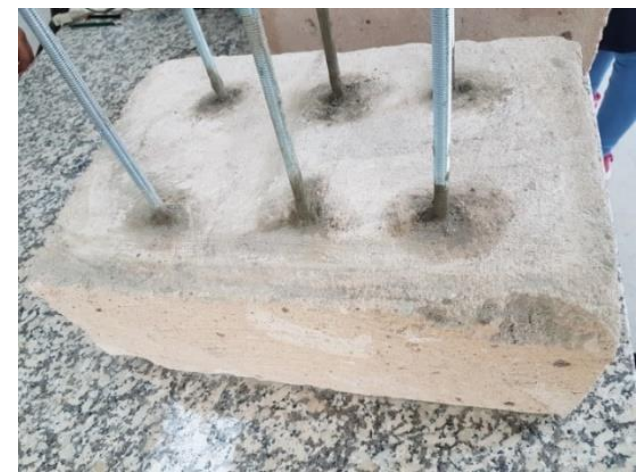

Şekil 7. Çimento şerbeti ile yapılan deney numunelerinin deney öncesi hali

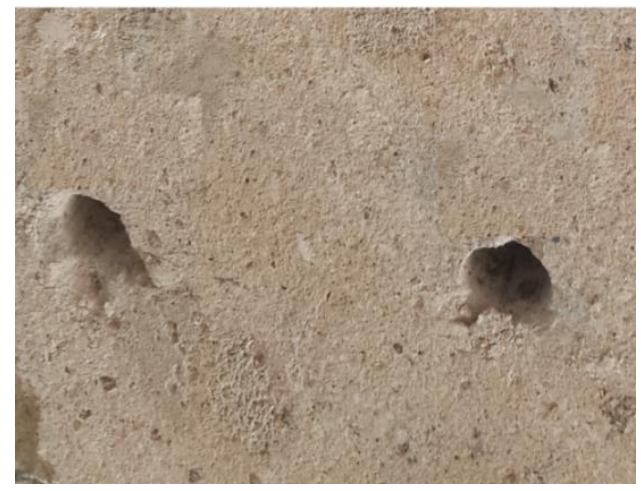

Şekil 8. Çimento şerbeti ile yapılan deney numunelerinin deney sonrası hali

\section{Araştırma Sonuçları ve Tartışma}

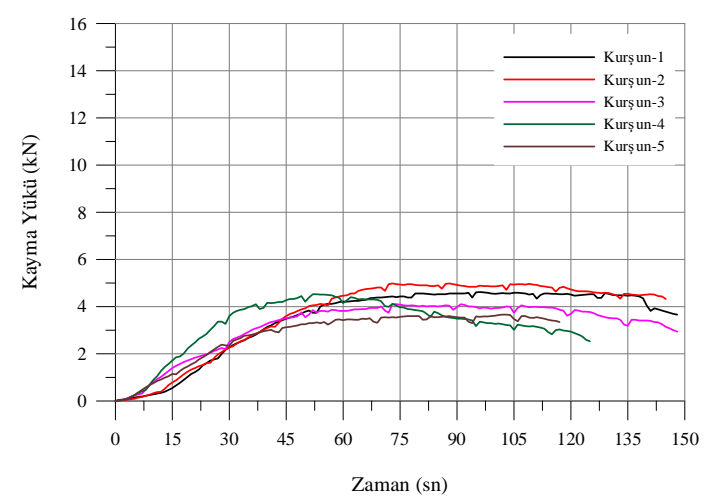

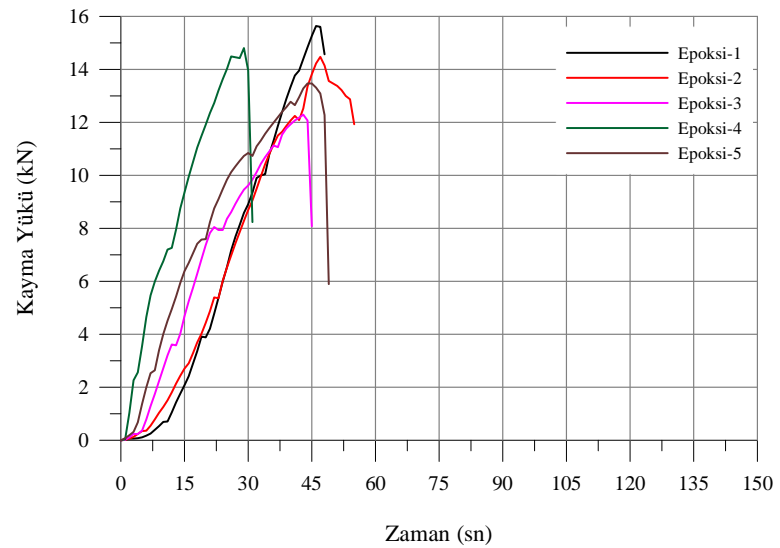

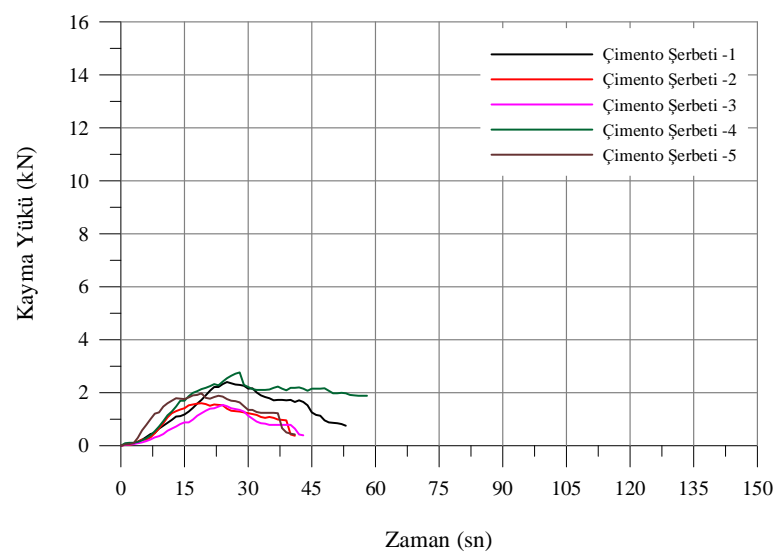

Şekil 9. Deney numunelerinin kayma yük-zaman grafikleri

Şekil 9'da deney numunelerinin kayma yük-zaman grafiği verilmiştir. Yapılan deneysel çalışmalar sonucunda epoksi ile taş bloğa sabitlenen zıvana ile yapılan deney numuneleri maksimum kayma yükünü taşırken, çimento şerbeti ile sabitlenen deney numuneleri ortalama $1,93 \mathrm{kN}$ ile en az yükü taşımışlardır. Epoksi ile yapılan deney numuneleri sonucuna bakıldığında taşta meydana gelen hasarlar kurşun ve çimento şerbeti ile yapılan deney numunelerine göre çok fazladır. Deney sonucunda epoksi ile yapılan deney numuneleri ortalama $11,92 \mathrm{kN}$ yük taşıyarak, taş bloklarda daha geniş çatlaklar oluşmuştur. Epoksi ile yapılan 5 adet deney numuneleri birbirlerine yakın davranış sergileyip, taşıdıkları maksimum kayma yükleri de birbirlerine yakın çıkmıştır. Epoksi deney numunelerinin taşıdıkları maksimum kayma yükleri $15,64 \mathrm{kN}, 14,47 \mathrm{kN}, 12,29 \mathrm{kN}, 14,81 \mathrm{kN}$ ve 13,47 kN'dur.

Yapılan deney sonuçlarına göre, çimento şerbeti ile yapılan deney numunelerinin en az kayma yüküne sahip olduğu görülmüş olup, çimento şerbeti ile taş bloklar üzerine açılan zivana yuvalarına sabitlenen zivalarda deney sirasinda sıyrılmalar meydana gelmiştir. çimento şerbeti ile yapılan 5 adet deney numunesi de epoksi malzemesi kullanılarak yapılan deney numuneleri gibi birbirlerine yakın davranış sergilemişlerdir. Deney sonucunda elde edilen kayma yükleri Deney 1 'den Deney 5'e kadar surası ile 2,40 kN, 1,60 kN, 1,54 kN, 2,76 kN ve 1,98 $\mathrm{kN}$ değerindedir.

Geçmişten günümüze kadar tarihi yapıların onarım ve güçlendirilmesinde kullanılan kurşun ile yapılan deney numuneleri, diğer deney numuneleri gibi birbirlerine oldukça yakın davranış sergilemişlerdir. Epoksi ile yapılan deney numunelerinde taşlarda gözlemlenen büyük hasarlar kurşun ile yapılan deney numunelerinde görülmemiştir. 
5 adet kurşun kullanılarak yığma taşlara sabitlenen zıvanalar ile yapılan deney numunelerinin deney sonucunda taşıdıkları kayma yükleri sırası ile 4,62 kN, 4,98 kN, 4,12 kN, 4,53 kN ve 3,66 $\mathrm{kN}$ 'dur.

Deney sonucunda deney numunelerinden elde edilen ortalama kayma yük-zaman grafiği Şekil 10'da gösterilmiştir. Şekilden de görüldüğü gibi en az kayma yükünü taşıyan deney numunesi, çimento şerbeti ile yapılmış deney numunesi olmuştur. Kurşun ile yapılan deney numunesi diğer deney numunelerine göre daha sünek bir davranış sergilerken, maksimum kayma yükünü taşıyan epoksi ile yapılmış deney numunesi gevrek bir davranış sergilemiştir.

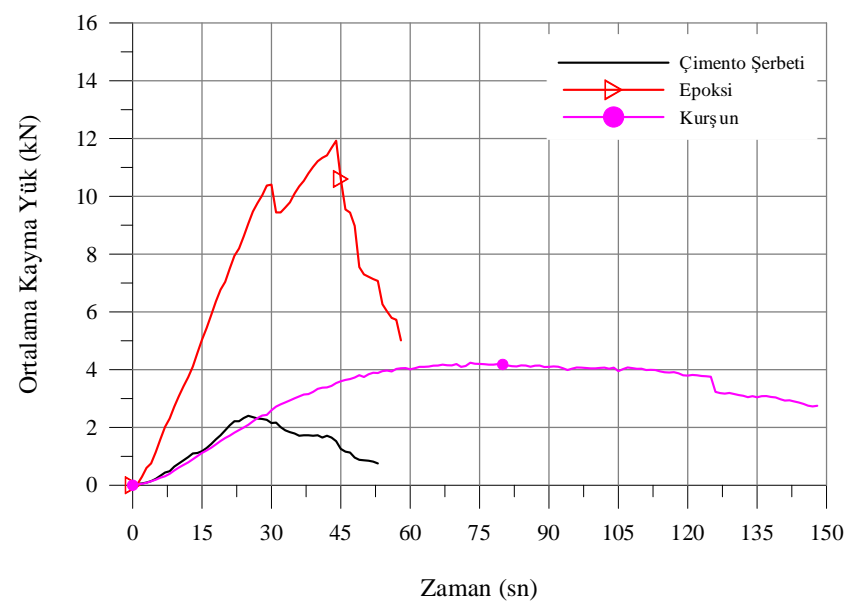

Şekil 10. Kurşun, epoksi ve çimento şerbeti ile yapılan deney numunelerinden elde edilen ortalama kayma yük-zaman grafikleri.

\section{Sonuç}

$\mathrm{Bu}$ çalışmada taş bloklarda düşey bağlantı elemanı olarak kullanılan zıvanaların farklı dolgu malzemeleri ile taş bloklara sabitlenmesiyle oluşturulan numunelerin kayma dayanımları incelenmiştir. Zıvanayı temsilen $10 \mathrm{~mm}$ çapına sahip sonsuz dişliler ve dolgu malzemeleri olarak da kurşun, epoksi ve çimento şerbeti kullanılmıştır. Her bir numuneden 5'er adet olmak üzere toplamda 15 adet deney numunesi hazırlanmıș ve bu numuneler üzerinde deneysel çalışmalar gerçekleştirilmiştir.

Deneysel çalışmalardan elde edilen sonuçlar maddeler halinde sunulmuştur.

- Zıvanaların sabitlenmesi için kullanılan epoksi malzemesi ile yapılan deney sonucunda, taş bloklar üzerinde büyük hasarlar gözlemlenirken, kurşun ve çimento şerbeti ile sabitlenen zıvanalarla yapılan deney sonucunda taş bloklar üzerinde çok fazla hasar gözlenmemiştir. Yapılan bütün deneylerde zıvanalar, akma noktasına gelmeden taş bloklar üzerinden ayrıldığı için zıvana yüzeyinde deformasyonlar görülmemiştir.

- Dolgu malzemesi çimento şerbeti kullanılarak yapılan deney numunelerinin ortalama maksimum kayma yükü 1,93 kN'dur. Çimento şerbeti ile yapılan deney numunelerinde deney sirasinda zivanalarda siyrılmalar meydana gelmiştir. Bu sebeple tarihi yapıların onarım ve güçlendirmesinde kullanılan zıvanaların, çimento şerbeti ile taş bloklara sabitlenmesi taşıma kapasitelerinde önemli bir artışa sebep olmamaktadır. Aynı zamanda bu numuneler zıvana ile bir bütünlük sağlamayarak, zıvananın hava koşullarından etkilenip korozyona uğramasına neden olmaktadır.

- Taş bloklar üzerine kurşun malzemesi kullanılarak sabitlenen zıvanalı deney numunelerinin, taşıdıkları ortalama maksimum kayma yükü 4,24 kN'dur. Geçmişten günümüze kadar geleneksel dolgu malzemesi olarak kullanılan kurşunun tarihi yapılardaki kullanımının ne kadar doğru olduğu bu çalışma ile desteklenmektedir. Kurşun ile yapılan deney numuneleri diğer numunelere göre daha sünek bir davranış sergilemiştir. Yığma yapılar da kullanılan taşlar gevrek bir malzeme olduğu için, deprem gibi yapıya gelen yatay yüklere karşı yapıların sünekliliğini arttıracak malzemelerin kullanılması oldukça önemlidir.

- Son zamanlarda tarihi yapıların onarım ve güçlendirilmesinde kullanılan, epoksi malzemesi ile sabitlenen zıvanaların, taş bloklar üzerindeki kayma dayanımı bu çalışma ile incelenmiştir. Deney numuneleri ortalama maksimum 11,92 kN'luk kayma yükü taşımıştır. Beklendiği gibi deney numunelerinin taş1dıkları kayma yükleri kurşun ve çimento şerbetine göre oldukça fazladır. Fakat epoksi ile yapılan deney numunelerinde taşların daha fazla hasar aldığı gözlenmiştir. Epoksi ve kurşun malzemesi zıvana ile iyi bir aderans sağlamış olmasına rağmen, epoksi ile yapılan deney numunelerinde, kurşunda olduğu gibi sünek bir davranış görülmeyip, gevrek bir davranış sergileyerek yükte ani düşmeler meydana gelmiştir.

- Yapılan bu çalışma ile tarihi yapıların onarım ve güçlendirilmesinde kullanılan zıvanaların taş bloklar üzerine sabitlenmesinde dolgu malzemesi olarak kurşunun kullanılmasının, yapı üzerinde dayanım ve süneklilik açısından daha iyi bir davranış sergilediği belirlenmiştir.

- $\quad \mathrm{Bu}$ çalışmanın, yapılacak olan tarihi yapıların onarım ve güçlendirme gibi restorasyon çalışmalarında iyi bir referans olacağı ve bundan sonra yapılacak bilimsel çalışmalara katkı sağlayacağı beklenmektedir. Bu çalışma ile farklı dolgu malzemeleri kullanılarak zıvanaların taş bloklar üzerindeki kayma dayanımları incelenmiştir. Fakat kenetlerin farklı dolgu malzemesi ile doldurulmasıyla oluşturulan numunelerin davranışlarının incelenmesi bir başka konu olarak önerilmektedir. 


\section{Kaynakça}

Çelik, T., ve Tanrıverdi, Ş. (2021). Farklı Çaplardaki Zıvanaların Kurşun İle Sabitlenmesinin Kayma Dayanımına Etkisi. Avrupa Bilim ve Teknoloji Dergisi, (24), 24-29.

Demir, C. (2012). Seismic behaviour of historical stone masonry multi-leaf walls (Doctoral dissertation, $\mathrm{PhD}$ Dissertation. Turkey: Istanbul Technical University (ITU)).

Nikolić, Ž., Smoljanović, H., \& Živaljić, N. (2019). Analysis of metal connector's effect on seismic resistance of dry stone masonry structures. Computational Methods in Structural Dynamics and Earthquake Engineering.

Özyurt, M. Z., Mohammad1, M., \& Cumhur, A. (2020). Genişletilmiş Çelik Levhalarla Güçlendirilmiş Blok Tuğla Duvarlarda Bulon Aralığının Dayanım ve Davranıș Üzerindeki Etkisi. Avrupa Bilim ve Teknoloji Dergisi, 365373.

Simonović, V., \& Simonović, G. (2018). Numerical Investigation of Possible Strengthening of Masonry Walls. In International Symposium on Innovative and Interdisciplinary Applications of Advanced Technologies (pp. 175-181). Springer, Cham.

Soti, R., \& Barbosa, A. R. (2019). Experimental and applied element modeling of masonry walls retrofitted with near surface mounted (NSM) reinforcing steel bars. Bulletin of Earthquake Engineering, 17(7), 4081-4114.

TS EN 772-1+A1. (2015). Kagir birimler-deney yöntemleribölüm 1: Basınç dayanımının tayini, Türk Standartları Enstitüsü, Ankara.

TS EN 772-6. (2004). Kagir birimler-deney metotları-bölüm 6: Beton kagir birimlerin eğilmede çekme dayanımının tayini, Türk Standartları Enstitüsü, Ankara.

TS EN ISO 6892-1. (2020). Metalik malzemeler-çekme deneyibölüm 1: Ortam sicaklığında deney metodu, Türk Standartları Enstitüsü, Ankara.

Ural, A., Kara, M. E., ve Uslu, S. (2015). Kenet ve Zivanaların Yığma Duvarların Kesme (Kayma) Davranışına Etkisi. 5. Tarihi Eserlerin Güçlendirilmesi ve Geleceğe Güvenle Devredilmesi Sempozyumu, Erzurum, 537-548, 2015.

URL-1: $\quad$ https://assets.master-builders-solutions.com/trtr/masterbrace\%20adh\%201406\%20(eski\%20ad\%C4\%B1\% 20concresive\%201406).pdf

URL-2: https://www.pinarmetal.com/pic/pdf/kursun.pdf 